\title{
THE EFFECT OF VINCRISTINE ON MORPHO-FUNCTIONAL STATE OF NEURONS OF CEREBROSPINAL SENSITIVE GANGLIONS IN EXPERIMENT
}

\author{
CN. Luchkiv
}

В експерименті на 31 щурі методами світлової та електронної мікроскопії, морфометричного аналізу встановлено, щзо вплив вінкристину проявлясться порушенням нейротрубочок $і$ нейрофіламентів в аферентних нейронах з ураженням білоксинтезуючих органел. У динаміці розвитку вінкристин-індукованих порушень нейронів та гліоцитів чутливих спинномозкових вузлів можна виділити дві основні стадї: 1) стадія неглибоких дистрофічних змін перикаріонів аферентних нейронів спинномозкових вузлів (7-а доба); 2) стадія глибоких дистрофічних порушень перикаріонів аферентних нейронів (8-21-а доби) Ключові слова: вінкристин, нейротоксичність, спинномозковий вузол, нейрони, гліочити,нейротрубочки, нейрофіламенти, стадія, порушення

\section{Introduction}

Vincristine belongs to the group of preparation of vegetable generation, gotten from the vegetable rose myrtle (Vinca rosea L.). This preparation has cytostatic activity and causes the reverse mitotic block, binding preparation with cytoplasmatic precursors of mitotic spindle [1]. It is considered, that cytotoxicity of vincristine is conditioned by its effect on membranes of tumor cells in phase $G_{1}$ of mitotic cycle [2]. That is vinca-alkaloids are combined in the group of inhibitors of microtubes [3].Vincristine belongs to the group of chemotherapeutic preparations with expressed neurotoxicity. The active use of this preparation in treatment of malignant tumors, especially in child age, conditions the topicality of studying vincristine influence on peripheral nervous system. In this connection, we studied the effect of this preparation of morpho-functional state of neurons and gliocytes of cerebrospinal ganglion of rat for the first time.

\section{Literary review}

Vincristine is used in oncology for treating patients with malignant tumors of different organs and systems of organism. But such side effect of vincristine as neurotoxicity limits the use of this preparation at treating malignant tumors. Vincristine is often used for treating cancer patients in complex with other chemopreparations but the number of neurotoxic complications doesn't decrease. Thus, R. A. Huddart et al. [4] determined the side manifestations of complex of carboplatin+methotrexat+ +vincristine+cisplastin during 5 years of observations, including peripheral neuropathy of 1 degree in $54 \%$ of cases and in $23 \%-2-3$ degree. Almost the same number of neurotoxic manifestations was detected by D. P. Dearnale et al. [5] at using biomycinum+etoposide+cisplastin+vincristine. The increase of number of neurotoxic lesions can take place at synchronous use of vincristine and verapamilum [6]. At treating acute lymphoblastic anemia by vincristine, the electrophysiological examination showed the disorder of sensitivity and significant reduction of M-waves amplitude [7].

The analysis of scientific literature testifies to the active use of vincristine in treating malignant tumors and study of neurotoxicity of this preparation. But the study of vincristine effect on nervous system as a whole and also on its separate components is topical for today.

\section{Aim and tasks of research}

Aim of the work - to study the morpho-functional state of neurons and gliocytes of sensitive cerebrospinal rat ganglion under effect of vincristine in experiment.

Task of research - to reveal the disorder of structural components of sensitive cerebrospinal ganglion, conditioned by vincristine use.

\section{Materials and methods}

The complex of light optical, morphometric and electromicroscopic methods of research was used to reveal the effect of vincristine use on structural components of sensitive cerebrospinal ganglion. The experimental study was carried out on 31 rats of both sexes (16 - experimental and 15 control ones) with mass $200,0-220,0 \mathrm{~g}$. The animals were kept in vivarium with free access to the food and water. The animals were fed with mixed fodder for laboratory rats that satisfied physiological needs of their organism in vitamins, microelements, mineral substances and energy. All manipulations with animals were realized with complete compliance with the requirements of "General ethical principles of experiments on animals", accepted by the First national congress of bioethics (Kyiv, 2001) with strict observance of recommendations of "European convention about protection of vertebral animals, used for experiments and other scientific aims" (Strasbourg, 1985), principles of the "Rules of pre-clinical estimation of safety of pharmacological preparations (GLP)" (2001) and rules of humane treatment of experimental animals, approved by commission of bioethics of SHEI "Ivano-Frankivsk national medical university", protocol No. 87/16 of 17.02.2016 that is testified by the correspondent report of bioethical expertise.

Vincristine (Vincristinum sulfuricum, made by Gedeon Richter, Hungry) was administered intravenously to animals, according to the model, offered by K. O. Aley et al. [8] every day during 2 weeks (Monday-Friday). 
The contents of bottle was dissolved in isotonic solution of $\mathrm{NaCl}$, in dose $100,0 \mathrm{mg} / \mathrm{kg}$ of body mass - totally 10 injections, summary dose $1000,0 \mathrm{mg} / \mathrm{kg}$. Material was collected in 3, 7, 14, 21 days after last administration of vincristine. The control animals were administered intravenously with equivalent volume of vehicle.

Paraffin cuts of cerebrospinal ganglions were colored by purple cresyl, according to Nissle. Morphometric analysis of preparations of cerebrospinal ganglions, colored according to Nissle method, was carried out in interactive regime by scanning successive images of all perikaryons of sensitive neurons that contain kernels, and the ones of kernels of mantle gliocytes, surrounding them. The parameters of area of profile field of perikaryon of esodic neuron were determined. The results of morphometric analysis were processed by the methods of variational statistics. The ultrathin cuts were prepared on ultramicrotome Tesla BS -490A and studied on electronic microscope TEM $-125 \mathrm{~K}$ at magnification from 4800 to 12000 times.

\section{Results of research and their discussion}

Under influence of vincristine during experiment the expressed sensitivity of neurons of sensitive cerebrospinal ganglions to the toxic influence of preparation was observed. The big neurons suffer most, the small ones least. In separate neurons chromatophilic substance looks as small grain and is distributed evenly in perikaryons. In other neurons chromatphilic substance looks as intensely colored clots on the background of light areas of cellular cytoplasm. The fine-nidal chromatolysis of chromatophilic substance is manifested in neurons during all time of experiment. Such regularity is described by K. S. Topp et al. [9], who studied the vincristine influence on esodic neurons of cerebrospinal ganglions in rats in early terms after administration of preparation.

Morphometric studies in 3 days after vincristine administration detected some decrease of neuron profile area to $(289,13 \pm 11,02) \mathrm{mcm}^{2}$, control - $(327,36 \pm$ $\pm 12,43) \mathrm{mcm}^{2}(\mathrm{p}>0,05)$. The decrease of profile area of neuron becomes more significant at 7 day and is $(272,05 \pm 9,45) \mathrm{mcm}^{2}$, against $(311,83 \pm 9,58) \mathrm{mcm}^{2}$ in control. At 14 day the insignificant increase of perikaryons sizes was observed - $(291,06 \pm 8,94) \mathrm{mcm}^{2}$, against $(315,61 \pm 17,88) \mathrm{mcm}^{2}$ in control $(\mathrm{p}>0,05)$. At 21 day the reliable decrease of neurons profile area comparing with previous term of experiment to $(245,34 \pm 9,46) \mathrm{mcm}^{2}$ on the background of control - $(332,19 \pm 12,78) \mathrm{mcm}^{2}$, $\mathrm{p}<0,05)$ was fixed.

Electromicroscopic study showed that the grouping of cisterns of granular endoplasmatic net was observed in neurons at 3 day of experiment. Free ribosomes and polysomes have a tendency to accumulation in different areas of perikaryons. The elements of cytoskeleton demonstrate disorder in location. Mitochondrias have different form and usual sizes. The external mitochondrial membrane and crests, created by external membrane, are kept. The matrix of mitochondrias is fine-granular with middle electronic density. Dictiosomes of Golgi apparatus are uncountable. The kernel structures don't demonstrate disorders. At the same time the neurons with widened lumens of follicles of granular endoplasmatic net occur. Somewhere are degranulated areas of membranes of cisterns of granular endoplasmatic net and mitochondrias with destructed crests.

The seventh day of experiment is characterized with further changes in the state of granular endoplasmatic net: shortening, moderate widening and deformation of cisterns and their chaotic location. There is observed the disorder of location of neurons cytoskeleton elements, uneven density of microtubes and microfilaments in cytoplasm. The separate cisterns of Golgi complex and smooth endoplasmatic net are widened, filled with material with different electric density. In mitochondrias the disorders in separate areas of external mitochondrial membrane are added to the changes of previous term. The number of lysosomes and osmiophilic inclusions in neuroplasm increases. So, it can be classified as intracellular manifestations of atrophic processes.

At 14 day the ultrastructural image is added with progressing of atrophy of granular endoplasmatic net on the background of neurons cytoskeleton disorder. The proliferation of components of Golgi complex with synchronous vacuolar transformation of its cisterns is revealed. The swelling, destruction of crests and areas of external and internal mitochondrial membranes are observed in predominant majority of mitochondrias.

In 21 day after vincristine administration the aforesaid changes deepen with expressed vacuolar transfrormation of cisterns of granular endoplasmatic net and mitochondrias.

The number of mantle gliocytes, surrounding neurons in cerebrospinal sensitive ganglion, doesn't change during experiment.

According to our data, since 14 day the dystrophic changes of mantle gliocytes are manifested. The moderate widening of follicles and tubes of endoplasmatic net is observed in them. The cytoplasm of gliocytes has moderate electronic density, is evenly filled with free ribosomes and polysomes. In several gliocytes the edema of hyaloplasm takes place. At 21 day of experiment there is an expressed proliferation of granular endoplasmatic net and Golgi complex. Mitochondrias are swelled, vacuolarly transformed with destruction of crests and local disorder of external mitochondrial membrane. Some destruction was observed also in plasolemma of gliocytes. The typical feature of changes of glial cells is an intensification of processes of protein synthesis on the background of disorder of ultrastructure of some mitochondrias.

The received results are agreed with data of A.Silva et al. [10], who demonstrated in experiment on the model of vincristine administration to animals that its manifestations are conditioned by degeneration of neurons and their outgrowths in cerebrospinal ganglions.

Accepting the fact that vincristine and other antitumor preparations (cisplastin, oxaliplatin, paclitaxel, bortezomib) are ones of most effective preparations that have effect (separately or in combination) as a first line therapy for most spread types of cancer, nevertheless, it is noted, that they are frequent cause of severe peripheral 
neurotoxicity and neuropatic pain. The structural disorders in cerebrospinal ganglions cause the symptoms of sensitivity loss, paresthesia, dysesthesia and numbness that result in suffering of patient. The cerebrospinal ganglions, containing sensor neurons and mantial gliocytes, according to B. A. Carozzi et al. [11] are the predominant areas, where chemotherapy causes neurotoxicity. RNA lesion, changes in the system of stem cells, changes of mitochondrias, increase of intracellular active forms of oxygen, changes in ionic channels, signalization of glutamate, MAP-kenases and nociceptors of activation among events there are the main moments of pathogenesis of peripheral neurotoxicity and neuropatic pain. In our work we established the vincristine effect on nerve structures of sensitive cerebrospinal ganglion in pathogenesis of vincristine-induced peripheral neuropathy on the base of received light optical, morphometric and electromicroscopic data.

\section{Conclusions}

On the base of aforesaid we come to the conclusion that the effect of vincristine is manifested by disorder of neurotubes and neurofilaments in esodic neurons with lesion of protein-synthesizing organobodies. Two main stages can be separated in the dynamics of development of vincristine-induced disorders of neurons and gliocytes of sensitive cerebrospinal ganglions:

1) the stage of not deep dystrophic changes of perikaryons of esodic neurons of cerebrospinal ganglions (7 day);

2) the stage of deep dystrophic disorders of perikaryons of esodic neurons (8-21 days).

\section{References}

1. Bulkina, Z. P. Protivoopuholevyie preparatyi [Text] / Z. P. Bulkina. - Kyiv: Naukova dumka, 1978. - 304 p.

2. Blohin, N. N. Himioterapiya opuholevyih zabolevaniy [Text] / N. N. Blohin, N. I. Perevodchikova. - Moscow: Meditsina, 1984. $-304 \mathrm{p}$.

3. Swain, S. M. Neuropathy associated with microtubule inhibitors: diagnosis, incidence and management [Text] / S. M. Swain, J. C. Arezzo // Clin. Adv. Hematol. Oncol. - 2008. - Vol. 6, Issue 6. - P. 455-467.

4. Huddart, R. A. Accelerated Chemotherapy in the Treatment of Urothelial Cancer [Text] / R. A. Huddart, F. N. Lau, T. Guerrero-Urbano, G. Jay, A. Norman, A. Horwich, D. P. Dearnaley // Clinical Oncology. - 2001. - Vol. 13, Issue 4. - P. $279-283$. doi: 10.1053/clon.2001.9269

5. Dearnaley, D. P. Adjuvant bleomycin, vincristine and cisplatin (BOP) for high-risk stage I nonseminomatous germ cell tumours: a prospective trial (MRC TE17) [Text] / D. P. Dearnaley, S. D. Fossa, S. B. Kaye, M. H. Cullen, S. J. Harland, M. P. J. Sokal et. al. // British Journal of Cancer. - 2005. - Vol. 92, Issue 12. - P. 2107-2113. doi: 10.1038/sj.bjc.6602624

6. Balayssac, D. Vincristine-induced neuropathy in the rat is not modified by drug-drug interactions with the P-glycoprotein inhibitor verapamil [Text] / D. Balayssac, A. Cayre, B. Ling, J. Maublant, F. Penault-Llorca, A. Eschalier et. al. // Chemotherapy. 2008. - Vol. 54, Issue 5. - P. 336-342. doi: 10.1159/000151540

7. Nishikawa, M. Targeting Superoxide Dismutase to Renal Proximal Tubule Cells Inhibits Mitochondrial Injury and Renal Dysfunction Induced by Cisplatin [Text] / M. Nishikawa, H. Nagatomi, B.-J. Chang, E. Sato, M. Inoue // Archives of Biochemistry and Biophysics. - 2001. - Vol. 387, Issue 1. - P. 78-84. doi: 10.1006/abbi.2000.2237

8. Aley, K. O. Vincristine hyperalgesia in the rat: A model of painful vincristine neuropathy in humans [Text] / K. O. Aley, D. B. Reichling, J. D. Levine // Neurosciense. - 1996. - Vol. 73, Issue 1. - P. 259-265. doi: 10.1016/03064522(96)00020-6

9. Topp, K. S. Damage to the cytoskeleton of large diameter sensory neurons and myelinated axons in vincristine-induced painful peripheral neuropathy in the rat [Text] / K. S. Topp, K. D. Tanner, J. D. Levine // The Journal of Comparative Neurology. 2000. - Vol. 424, Issue 4. - P. 563-576. doi: 10.1002/1096-9861(20000904)424:4<563::aid-cne1>3.3.co;2-1

10. Silva, A. Evidence for direct axonal toxicity in vincristine neuropathy [Text] / A. Silva, Q. Wang, M. Wang, S. K. Ravula, J. D. Glass // Journal of the Peripheral Nervous System. - 2006. - Vol. 11, Issue 3. - P. 211-216. doi: 10.1111/j.15298027.2006.0090.x

11. Carozzi, V. A. Chemotherapy-induced peripheral neuropathy: What do we know about mechanisms? [Text] / V. A. Carozzi, A. Canta, A. Chiorazzi // Neuroscience Letters. - 2015. - Vol. 596. - P. 90-107. doi: 10.1016/j.neulet.2014.10.014

Рекомендовано до публікації д-р мед. наук, професор Геращченко С. Б. Дата надходження рукопису 05.01.2017.

Natalia Luchkiv, PhD, associate professor, Department of histology, cytology and embryology, Ivano-Frankivsk National Medical University, Halytska str., 2, Ivano-Frankivsk, Ukraine, 76018

E-mail: ms.luchkiv@mail.ru 